\begin{tabular}{c|l}
\begin{tabular}{c|c} 
Issues in & An Official Publication \\
of the Informing Science Institute \\
InformingScience.org
\end{tabular} \\
\begin{tabular}{c|l} 
Informing Science + \\
IISIT.org
\end{tabular}
\end{tabular}

Volume 14, 2017

\title{
THE WORKFORCE FOR THE 21ST CENTURY
}

\author{
Henry O'Lawrence * \\ California State University Long \\ * Corresponding author \\ Beach, Long Beach, CA, USA
}

Henry.OLawrence@csulb.edu

\section{ABSTRACT}

Aim/Purpose

In today's changing economy, economic growth depends on career and technical programs for skill training.

Background

This study discusses the key area in promoting individual learning and skill training and discusses the importance of career education and training as a way of promoting economic growth.

Methodology

This study uses a qualitative study approach to investigate and report on the status and influence of Workforce Education and Development and its economic importance.

Contribution

This report contributes to the knowledge base common to all work settings that can solve many human performance problems in the workplace.

Findings

This study also justifies and validates the ideas on the importance of workforce education and development in the $21^{\text {st }}$ century as a way of developing economic growth and providing learning to make individuals competitive in the global economy.

Recommendations For practitioners, this study suggests that we must always have discussions of for Practitioners what leads to career success and understanding that there is not enough highskill/high-wage employment to go around. Therefore, developing these skills requires a decision about a career or related group of jobs to prepare to compete for them; we have to provide training needed in order to be competitive in global economy.

Recommendation Researchers have to develop strategies to promote career direction with willingfor Researchers ness to evaluate the level of academic interest, level of career focus and readiness for life away from home (attitudes, skills and knowledge of self).

Impact on Society Institutions must regularly evaluate curriculum to reflect the rapid technological changes and the globalization of world markets that reflect their mission and develop students' mindset to always think big and think outside the box in order to be competitive in the global market. Change is external, transition is internal. It is important that the change agent communicate both the reasons for change and the probable consequences that people will experience during the time of this change, which is transition - a change people go through when they become unemployed or face a major employment obstacle in their lives.

Accepting Editor: Eli Cohen | Received: December 5, 2016 | Revised: January 31, 2017 | Accepted: January 31, 2017. Cite as: O'Lawrence. H. (2017). The workforce for the 21st century. Issues in Informing Science and Information Technology Education, 14, 67-85. Retrieved from http://www.informingscience.org/Publications/3724

(CC BY-NC 4.0) This article is licensed to you under a Creative Commons Attribution-NonCommercial 4.0 International License. When you copy and redistribute this paper in full or in part, you need to provide proper attribution to it to ensure that others can later locate this work (and to ensure that others do not accuse you of plagiarism). You may (and we encourage you to) adapt, remix, transform, and build upon the material for any non-commercial purposes. This license does not permit you to use this material for commercial purposes. 
Workforce for the 21st Century

Future Research New research should focus on career assessment materials and related academic programs and career directions that will promote success.

Keywords workforce development, technology, unemployment and employment growth, labor force, education and job training, economic growth and instructional technology

\section{INTRODUCTION}

Workforce education and development is the key to promoting individual learning and skill training. Career and technical educators throughout the nation are affected by what goes on globally because of new developments, improved communication, faster travel, and increased commerce, which lead to global competition. What makes some nations rich, with their citizens enjoying a high standard of living, is commerce, that is, producing, selling, and buying goods and services that lead to jobs, individual wealth, and a high standard of living. For a nation to be competitive in a global economy, its human capital (workers) must be trained and educated to develop its natural resources and able to improve productivity and technology (Gordon, 2008; Gray \& Herr, 1998a; O’Lawrence, 2008b).

Natural resources, technology, and human capital are important strategic economic advantages. Human capital is the most important of the three; the most important elements in the quest for a competitive advantage in commerce are the skills and initiative of a nation's workforce. Technology is only as good as the ingenuity of those who can both maintain and use it to its fullest potential. Those who have a workforce that can use the technology to the fullest will have the advantage over those who cannot, and those with the highest skilled labor force will be able to adopt technology faster and use it to produce the best quality at the lowest price (Gray \& Herr, 1998a; Thurow, 1992).

Indicators suggest that the U.S. has the worst-educated unskilled nonprofessional/hourly workforce among the major economic powers because of a lack of investment in workers' training and retraining (Chao, 2006). The U.S. postsecondary education system represents the education of our workforce. Higher education has been a principal means of social mobility for many acculturating immigrants and for empowering minorities (Allen, 2002). Vocational education, increasingly known as career and technical education, is a longstanding program that continues to evolve in American education. The broadening of its goals, its participants' widening diversity, and the changing education and labor market climate in which it operates suggest vocational education programs are a flexible option for colleges and students (Silverberg, Warner, Fong, \& Goodwin, 2004).

This study identifies and reports on (a) major factors that influence the nation's economy, (b) how well the unemployment rate is controlled, (c) the labor force, (d) employment growth, and (e) how committed the nation is to educating the labor force. These five areas prove in the analysis that they should be considered seriously, as they lead to increased global competitiveness. History also tells us that no society can long survive unless the society as a whole becomes aware that meaningful work, done well, and dedication are essential aspects of a worthwhile life. This should be made known in our classrooms and should be one of the major goals of education. It is important in the $21^{\text {st }}$ century to reexamine and debate the importance of workforce education-corporate training and human resources development-on our economy: globally, federally, statewide, regionally, and locally. As we continue to review the current status of the economy, we should be concerned with unemployment, especially why college graduates can secure only mediocre jobs or nothing at all, and why our veterans are on the streets, homeless, jobless, and unwanted (O'Lawrence, 2008b, 2016).

When thinking about these issues, policymakers should consider the importance of workforce skill and retraining programs that benefit individuals seeking training for employment. As a result of these issues, this report proposes that political leaders and educational policymakers anticipate the nation's changing employment needs and facilitate better fits among high school graduates, college graduates, veterans returning from war, and employment opportunities. Workforce development programs allow students to acquire the special competencies associated with a particular vocation after they have learned something about their own special aptitudes and capacities, understand the range of work 
specializations available to them, and know the requirements and rewards associated with different occupational pursuits.

This analysis is divided into four different sections: unemployment rate, labor force, employment growth, and the importance of career and technical education programs. Today's college students realize the impact of information technology on society, the global phenomenon of world of competitiveness brought about by new characteristics of mass communication, and the potential for bringing remote parts of the world to the forefront of economic development. Indeed, the world is becoming flatter and virtually smaller every day. The influence of technology on education includes developments designed to provide almost instant communication from one geographical area to another. It is a way of social life, frequently linked with communication and motivation for social change (Friedman, 2007). Information technology has brought rapid transmission of news, and events create consequences that other nations consider immediately, such as creating businessindustrial mechanisms that cannot be reversed.

In international relations, the art of diplomacy has been affected in various ways by the use of information technology. This has served to enhance our understanding of third-world countries and other parts of the world. The world is overwhelmingly different in this regard from what it was and the universal tool of today-computer technology—is a global tool that has come to stay. If technology does not destroy us as a society, it will eventually make us a better society. Information technology brought educational reform to a changing society with the anticipation that education would be much better than in the past. However, there is tremendous concern among both politicians and educators that we might be heading toward the collapse of education structures if precautions are not taken. The question remains whether technology will make us or breaks us in the global economy, help us maintain our status as a superpower, and, of course, make us competitive. What would break us is our refusal to acknowledge the importance of career technical education, skill training, and retraining of citizens (O'Lawrence, 2007).

It is questionable as to why change occurs so slowly in our attitudes toward the value and necessity of vocational or occupational education, career technical education, and workforce development. Those in this field are held in the highest esteem, and their work ethic is fundamental to the value system that prepares us for the meaningful work that our economy, community, and society deserve. Workforce development education trains the mind, inculcates values, and strengthens the individual's capacity for responsible citizenship. It is important to recognize that workforce competence is the ability to use one's talents constructively toward productive ends that are economically valuable in the marketplace and is an important aspect of responsible citizenship (O'Lawrence, 2008a).

Our nation's schools' response to changing needs and opportunities can be viewed in the context of three fundamental educational tasks: socialization, social mobility, and individual self-realization. Our task is to educate, leading to the ability to participate constructively in the global economy, engage in policy, and advance the social-civic life of society by using information technology to produce a flexible labor force that will react effectively to the labor market. It is important to continue to find ways to develop curricula appropriate to students with special interests and abilities so that they can succeed in workforce related competencies. It is important to continue business and government support for higher education to help colleges and universities meet the challenges of a new economy (Barrow, 2000). Barrow (2000) indicates that higher education administrators also have to agree that curricula need to continue to focus more on areas that are significant to economic growth:

- Symbolic skills (conceptual, mathematical, and visual), not only specialized disciplinary content,

- Research skills, rather than established expertise, and

- Communications skills (oral and written), rather than mere "self-expression".

The only way these can be achieved is when higher education institutions can produce a workforce that is highly educated and trained. As capital becomes globally mobile, a solid strategy for high-wage 
developed nations to attract private capital investment will be through the skills and productivity of its domestic workforce. The $21^{\text {st }}$ century workforce and higher education must be positioned to respond to the global challenge to our economy and human resources. The workforce and higher education must ensure that students identify potential occupations as soon as possible along with the type of education and training needed for those occupations in order to be prepared and competitive. There is a need for articulation agreements among business, government, colleges, and universities to help promote and coordinate course work that will lead to real jobs and sustainable growth (Barrow, 2000; O’Lawrence, 2016).

\section{ANALYSIS AND FINDINGS}

\section{THE UNEMPLOYMENT RATE IN THE UNITED STATES}

Every two years the Bureau of Labor Statistic publishes projected U.S. economic factors that form the basis for the employment projections program. The unemployment rate is normally reported by the U.S. Bureau of Labor Statistics. The unemployment rate in the U.S. averaged 5.83\% from 1948 until 2014. The U.S. Department of Labor (2006) reported that in the first half of 2006 the unemployment rate averaged $4.7 \%$, lower than the $5.1 \%$ average of 2005 and a full point lower than the $5.7 \%$ average unemployment rate of the $1990 \mathrm{~s}$. A comparison of France and Germany shows that both countries have persistent unemployment rates nearly double that of the U.S. and their long-term unemployment of 12 months or more is nearly triple that of the U.S. More than 5.4 million net new jobs had been created in the United States since August 2003 (Chao, 2006). In addition to projected employment growth the recovery of the housing market, improved consumer confidence, strong business investment, rising medical expenses, and narrowing of the trade deficit also characterize the outlook of the U.S. economy in 2020.

Table 1 reports the unemployment rate between 2004 and 2014

Table 1: Labor Force status of Unemployment rate between 2004 and 2014 for 16 years old and over

\begin{tabular}{|l|l|l|l|l|l|l|l|l|l|l|l|l|}
\hline Year & Jan & Feb & Mar & Apr & May & Jun & Jul & Aug & Sept & Oct & Nov & Dec \\
\hline $\mathbf{2 0 0 4}$ & 5.7 & 5.6 & 5.8 & 5.6 & 5.6 & 5.6 & 5.5 & 5.4 & 5.4 & 5.5 & 5.0 & 5.4 \\
\hline $\mathbf{2 0 0 5}$ & 5.3 & 5.4 & 5.2 & 5.2 & 5.1 & 5.0 & 5.0 & 4.9 & 5.0 & 5.0 & 5.0 & 4.9 \\
\hline $\mathbf{2 0 0 6}$ & 4.7 & 4.8 & 4.7 & 4.7 & 4.6 & 4.6 & 4.7 & 4.7 & 4.5 & 4.4 & 4.5 & 4.4 \\
\hline $\mathbf{2 0 0 7}$ & 4.6 & 4.5 & 4.4 & 4.5 & 4.4 & 4.6 & 4.7 & 4.6 & 4.7 & 4.7 & 4.7 & 5.0 \\
\hline $\mathbf{2 0 0 8}$ & 5.0 & 4.9 & 5.1 & 5.0 & 5.4 & 5.6 & 5.8 & 6.1 & 6.1 & 6.5 & 6.8 & 7.3 \\
\hline $\mathbf{2 0 0 9}$ & 7.8 & 8.3 & 8.7 & 9.0 & 9.5 & 9.5 & 9.5 & 9.6 & 9.8 & 10.0 & 9.9 & 9.9 \\
\hline $\mathbf{2 0 1 0}$ & 9.8 & 9.8 & 9.9 & 9.9 & 9.4 & 9.4 & 9.4 & 9.5 & 9.0 & 9.4 & 9.8 & 9.3 \\
\hline $\mathbf{2 0 1 1}$ & 9.2 & 9.0 & 9.0 & 9.1 & 9.1 & 9.1 & 9.0 & 9.0 & 9.0 & 8.8 & 8.6 & 8.5 \\
\hline $\mathbf{2 0 1 2}$ & 8.3 & 8.3 & 8.2 & 8.2 & 8.2 & 8.2 & 8.2 & 8.0 & 7.8 & 7.8 & 7.7 & 7.9 \\
\hline $\mathbf{2 0 1 3}$ & 8.0 & 7.7 & 7.5 & 7.6 & 7.5 & 7.5 & 7.3 & 7.2 & 7.2 & 7.2 & 7.0 & 6.7 \\
\hline $\mathbf{2 0 1 4}$ & 6.6 & 6.7 & 6.6 & 6.2 & 6.3 & 6.1 & 6.2 & 6.1 & 5.9 & 5.7 & 5.8 & 5.6 \\
\hline
\end{tabular}

Adapted from the Labor Force Statistics from the Current Population survey

(Series Id: LNS14000000)

Most of the new jobs projected for the future are expected to be filled by persons with postsecondary education credentials. Workers who bring to the labor market the knowledge and skills that the competitive economy demands are able to secure positions with rising compensation; those who do not keep up with the relevant workplace knowledge and skills increasingly lag behind in employment and earnings. Provisions must be made by the institutions of higher learning to ensure that all stu- 
dents have access to the information, training, and resources that will help them acquire the skills they need to access the growing employment opportunities in our nation's $21^{\text {st }}$ century economy (Chao, 2006; Gray \& Herr, 1998a; O’Lawrence, 2013).

The recent report from the Bureau of Labor Statistics (BLS, 2014) indicated that the economy grew at an annual rate of $4 \%$ in the second quarter of 2014; if that rate continues that would mean that the growth rate has now been consistent with past recovery and the unemployment rate stands at $6.2 \%$ while job gains occurred in the areas such as professional and business services, manufacturing, retail trade, and construction. The GDP growth rate informs us how fast a county's economy is growing. When the economy is expanding the GDP growth rate become positive, and, if it is growing, business, jobs, and personal income become positive as well. The following facts were summarized:

- Business investment in the second quarter of 2014 rose by $5.5 \%$ after rising a meagre $1.6 \%$ in the first quarter and making policy makers wonder if the corporations would increase spending.

- In the housing sector realized an increase in investment which rose by $7.5 \%$ after two quarters of decline; an indication that the housing market might be improving.

- The manufacturing sector expanded in July 2014 for the 14 th consecutive month.

In another study as recently as November 7, 2014, the jobs report included seven million Americans in part-time work because they could not find full employment; and only $35 \%$ registered voters believed that the economy was getting better despite the official employment statistics that show unemployment is at its lowest level of 5.8\% since mid-2008 (Wessel, 2014).

\section{THE LABOR FORCE}

The U.S. is known as a leader in workforce productivity; however, what distinguishes the United States from other productivity leaders, such as France, is that the U.S. workforce is also a leader in work effort, that is, hours on the job. Hours worked per capita is a single measure of the labor activity across the population - taking into account both the portion of the population that is employed and the number of hours' people work. Sommers and Franklin (2012) discussed employment outlook from 2010-2020 and in their overview of projections to 2020 in the monthly labor review that features the Bureau of Labor Statistics (BLS) 2010-2020 employment projections. These projections suggest a slow labor force growth and a gross domestic product growth of $3.0 \%$ annually that would result in a gain of 20.5 million between 2010 and 2020. Industries and occupations related to healthcare and construction are projected to the fastest job growth.

For concepts and definitions, Gross Domestic Product (GDP) is defined as the value of all market and some nonmarket goods and services produced within a country's geographic borders. GDP is the most comprehensive measure of a country's economic output that is estimated by statistical agencies. GDP per capita may, therefore, be viewed as a rough indicator of a nation's economic wellbeing, while GDP per hour worked can provide a general picture of a country's productivity (Sommers \& Franklin, 2012).

The country with the highest GDP per capita, Norway, had a GDP per capita value in 2011 that was more than twice that of the country with the lowest value, the Czech Republic. In 2011, real GDP per capita grew in 18 of the 20 countries compared with the largest increases occurring in the Republic of Korea and Singapore. The GDP per hour worked is an indicator of a country's productivity. For example, in 2011 Norway had the highest level of GDP per hour among the countries covered and approximately 20\% higher than the next highest ranked country, Ireland, and roughly three times the level of the Republic of Korea. While Singapore had the second highest level of GDP per capita, it had a relatively low GDP per hour worked. Overall, countries with low levels of GDP per hour worked, such as Singapore and the Republic of Korea, had a high number of annual average 
hours worked per employed person. In general, European countries had a lower number of average annual hours worked than non-European countries, and average annual hours were lowest in Germany and Norway while the European country with the highest level of average annual hours worked was the Czech Republic, followed by Italy (BLS, 2012c). For international comparisons of levels of GDP, GDP per capita, or GDP per hour worked, the output has to be measured in a common currency unit. BLS converts the output measures from national currency units to U.S. dollars through the use of purchasing power parities (PPPs). PPPs are currency conversion rates that allow output in different currency units to be expressed in a common unit of value - in this case U.S. dollars. The PPP for a given country is a ratio, where the numerator is the number of national currency units needed to purchase a specific basket of goods and services in that country and the denominator is the number of U.S. dollars needed to purchase a similar basket of goods in the United States, the base country (BLS, 2012c).

With respect to the economic indicators previously discussed, the United States generally has led most other Organization for Economic Cooperation and Development (OECD) nations since 2000. The same holds true across most labor market measures, and it reflects strength throughout the U.S. labor market. At 5.1\%, the U.S. unemployment rate in 2005 was well below that of most of its European peers. Both Japan and South Korea benefited from even lower rates, continuing long-term trends for both countries. The United Kingdom's rate has hovered around 5\% for several years, after trending down from more than 10\% in 1993 (BLS, 2012c).

Among the major worker groups, unemployment rates for adult women $(7.3 \%)$ and Blacks $(14.0 \%)$ edged up in December, while the rates for adult men (7.2\%), teenagers $(23.5 \%)$, Whites $(6.9 \%)$, and Hispanics $(9.6 \%)$ showed little or no change. The jobless rate for Asians was $6.6 \%$ (not seasonally adjusted), which was little changed from a year earlier. In December 2012, the number of long-term unemployed (those jobless for 27 weeks or more) was essentially unchanged at 4.8 million and accounted for $39.1 \%$ of the unemployed. It was projected that the U.S. labor force will reach 163.5 million in 2020 and the growth in the labor force from 2012 -2020 was also predicted to be smaller than in the previous 10-year period between 2002-2012 when the labor force grew by 10.1 million resulting to about $0.7 \%$ annual growth rate (Bureau of Labor Statistics, 2013a).

\section{EMPLOYMENT GROWTH}

The best route to low unemployment is strong employment growth which also accompanies economic growth. The labor markets of both the United States and the European Union are quite similar in size, which offers opportunities for comparison on measures pertinent to the discussion. Between 1990 and 2005, civilian employment in the United States rose 19.3\%, while the comparable measure for the European Union rose 11.1\%. Since 2003, the United States again has taken the lead, while a number of European countries have seen somewhat stagnant employment growth, most notably France and Germany (U.S. Department of Labor, 2008).

In 2013 , the national unemployment rate was at $7.3 \%$ as the jobless rate decreased from $8.1 \%$ in 2012; among gender and race analysis, the unemployment rates for adult men (7.1\%), adult women $(6.3 \%)$, teenagers $(22.7 \%)$, whites $(6.4 \%)$, blacks $(13.0 \%)$, and Hispanics $(9.3 \%)$ had little change. The jobless rate for Asians was 5.1\% (not seasonally adjusted), little changed from a year earlier (Bureau of Labor Statistics, 2013a).

The Bureau of Labor Statistics (2013a) also estimated that anywhere between 300,000 and 500,000 U.S. jobs have already been lost and a projected 6 million U.S. jobs will be outsourced in 2014. Recent advancements in technology, trading commodities has becoming even more necessary for businesses across the world. S. P. Brown and Siegel (2005) define outsourcing as the movement of work that was formerly conducted in-house by employees paid directly by a company to a different company while the different company can be located inside or outside of the United States and the work can occur at a different geographic location or remain onsite. They also defined offshoring as the movement of work from within the United States to locations outside of the United States that can occur 
within the same company and involve movement of work to a different location of that company outside of the United States or to a different company altogether.

The Bureau of Labor Statistics (2015) reported that unemployment rate was essentially unchanged at $5.0 \%$ with job gains occurring in professional and business services such as healthcare (added 45,000 new jobs in October), retail trade (added 44,000 new jobs), food services and drinking places (added 42,000 new jobs), and construction (added 31,000 new jobs). Accordingly, and as reported, the unemployment rate of $5 \%$ and the number of unemployed about 7.9 million people were essentially unchanged in October; and over the past 12 months, both the unemployment and the number of unemployed people were down by only 0.7 percentage point and 1.1 million respectively. The following were also reported:

- The unemployment rates for adult men is $4.7 \%$

- The unemployment rates for adult women is $4.5 \%$

- For Teenagers $15.9 \%$

- Whites $4.4 \%$

- Blacks $9.2 \%$

- Asians $3.5 \%$ and

- Hispanics $6.3 \%$

In this age of globalization, companies have developed a new kind of trade, offshore outsourcing, which is the subcontracting of U.S. jobs to foreign workers. Hundreds and possibly thousands of U.S. companies have jumped on the outsourcing bandwagon, transferring a number of U.S. jobs to workers in foreign countries, resulting in unemployment for many American citizens. Offshore outsourcing is a growing economic trend that is costing thousands (and eventually millions) of United States workers their jobs; without federal restrictions set on private companies, Americans will continue to lose their jobs to workers in developing countries due to reduced labor costs and technological advancement that is allowing work to be completed all around the world

Arguments made during the 2012-2013 presidential election indicated more jobs will be created and new programs will be developed to allow U.S. workers who have lost their jobs to find work in other fields. This assertion is based on past economic trends, and not on fact. How are the thousands of U.S. workers who have already lost their jobs being impacted? Offshore outsourcing is a growing trend, and it will continue to grow as long as competition exists. For example, the International Finance Corp., which is one of the World Bank's investment arms, plans to sell $\$ 1$ billion of rupee bonds offshore to fund its investments as India struggles to lure capital amid the slowest growth in a decade in order to attract greater foreign investment due to economic uncertainty across the world (Cao, Xie, \& Rodrigues, 2013).

This trend has potentially harmful effects on American job prospects. As of October 2014, sixteen percent of Americans are still in poverty and not working based on the recently Census Bureau report on income and poverty. This is an indication that more needs to be done in creating jobs for the citizens. The question for us to answer is whether many Americans were much better off in the year 2000 than they were in 2013 (Doar, 2014). Are they better off today?

Another consideration is to examine the extent to which employers assist dislocated workers.

Reemployment is one possibility. Important factors affecting reemployment include the availability of both financial and placement assistance. Most establishments that experience a closure or a permanent layoff provide some assistance to the workers who are now dislocated. Slightly more than one half of the businesses experiencing a closure or a permanent layoff offered their workers severance pay, about one third offered placement assistance, and 3\% offered occupational training. According to the U.S. Bureau of Labor Statistics (2012b), about 6.1 million workers were displaced from jobs held for at least three years, down from 6.9 million for the survey period covering January 2007 to 
December 2009. However, in January 2012, 56\% of workers displaced between 2009 and 2011 were reemployed, up by seven percentage points from the prior survey in January 2010.

The period covered by Bureau of Labor Statistics was in 2009-2011, the three calendar years prior to the January 2012 survey date; and the period was characterized by modest employment growth (Bureau of Labor Statistics, 2012b). The following are the highlights of the January 2012 survey.

- In January 2012, 56\% of the 6.1 million long-tenured displaced workers were reemployed, up from 49\% for the prior survey in January 2010.

- About 40\% of long-tenured displaced workers from the 2009-2011period cited insufficient work as the reason for their displacement, and 31\% cited that their plant or company closed down or moved.

- About one out of five long-tenured displaced workers lost a job in manufacturing.

- Among long-tenured workers who were displaced from full-time wage and salary jobs and who were reemployed in such jobs in January 2012, 46\% had earnings that were as much or greater than those of their lost job (Bureau of Labor Statistics, 2012b).

The trauma of job loss and immediate loss of income, coupled with the competition for jobs by hundreds of workers with the same skills and experience, create overwhelming problems for displaced workers. Education and training should reach out to those affected by job loss by improving existing services to guarantee a better-prepared workforce to meet the challenges of the 21 st century.

Training is not only for school-age students, but also for older workers. The major question to ask is if the current system of education was designed to produce the well-rounded skill and education that can lead to gainful employment after graduation. Several reports indicate that the United States is falling behind its competitors in the quality and quantity of education it provides to young people entering the workforce. It is also true that in many highly industrialized countries, the adult basic education system is intended to enable a much larger fraction of the adult population to achieve much higher education standards. It is also true that most of those countries have national occupational skills standards and curricula designed in a modular form so that people can accumulate modules as they need them to achieve their personal goals or adjust to changes in the patterns of job availability as the economy changes. Also, their financial aid systems are designed to help workers take advantage of these modular programs or are offered to workers free of charge (Bureau of Labor Statistics, 2012b).

\section{IMPORTANCE OF CAREER AND TECHNICAL EDUCATION}

According to the US Department of Labor (2008), many jobs required no more than basic literacy and physical skills largely learned through experience. The proportion of persons' ages 25 to 64 years old with some college (or an associate degree) more than doubled between 1970 and 2005 (from $11.8 \%$ to $27.8 \%$ ). The share with a bachelor's degree or higher also more than doubled during the period (from $14.1 \%$ to $32.3 \%$ ). In contrast, the share of the labor force with less than a high school diploma declined markedly. In 2005, 32.3\% (38.9. million) of labor force members ages 25 to 64 had earned a bachelor's degree or higher, $27.8 \%$ (33.4 million) had undertaken some college but had not attained a baccalaureate degree, $30.1 \%$ (36.3 million) had attained only a high school diploma (or GED certificate), and $9.8 \%$ (11.8 million) had attained less than a complete high school education (no diploma or GED certificate). The number of people ages 25 to 64 in the labor force with less than a complete high school education fell by nearly half (47.1\%) since 1970. During that period, the number of persons with some postsecondary education (some college, associate degree, bachelor's degree, or higher) increased from 16.0 million (25.9\% of the labor force ages 25 to 64 ) to 72.4 million $(60.1 \%$ of the labor force ages 25 to 64) (U.S. Department of Labor, 2008). Fewer and fewer jobs now can be properly performed with only basic literacy and physical skills. Enhanced education 
and advance occupational skill are becoming more of a necessity for gainful employment with high wage earning potential.

The relationship between educational attainment and wages is strong and positive. Among workers 25 years and older, the median weekly wage and salary earnings among workers who usually work full time and are high school graduates are nearly $2 \frac{1}{2}$ times more than those who have not completed high school. The weekly difference of $\$ 604$ in 2005 would amount to an annual difference of $\$ 31,408$ if extended throughout a 52 -week year. The trends in educational attainment are closely associated with the trends in the occupational and industrial structure of the labor market, especially the growth in the demand for workers who provide professional, technical, and managerial services (U.S. Department of Labor, 2008).

The demand for a highly educated workforce is expected to continue. The U.S. Department of Labor (2013) "Economic News Release" projections for 2004 through 2014 indicate that nearly two thirds $(63.4 \%)$ of the projected 18.9 million new jobs will most likely be filled by workers with some postsecondary education. Prior to 2000 , it was also predicted that the majority of jobs would require a postsecondary degree (Farmer \& O'Lawrence, H., 2002; Gray \& Herr, 1998a). While most of the 18.9 million new job openings will be in occupations for which workers with higher educational attainment will be the most suited, there will also be many jobs available for those with less education. In addition to growth, the Bureau of Labor Statistics projections estimate openings because of net replacement need-replacement of workers who permanently leave occupations because of retirement or other reasons. The beginning of retirement of the baby-boom generation throughout the next several years will contribute to replacement openings across occupations and will impact many jobs across a range of educational requirements.

Between 2004 and 2014, the U.S. Department of Labor (2013) projections show that the number of net replacement openings will total 35.8 million and total openings for both growth and net replacement needs will be 54.7 million. In general, occupations in the high-school-or-less educational requirements cluster will account for a greater share of replacement job openings than growth job openings because many of those occupations have a high turnover, an aging incumbent workforce, and relatively large replacement needs despite slower relative growth.

According to U.S. Bureau of Labor Statistics report in April (BLS, 2013b), about 46.2 million people $(15 \%)$ of the nation's population lived below the official poverty level, and the report classified those people primarily as children and adults who had not participated in the labor force during the year.

About 10.4 million individuals were considered the working poor in 2011(those who spent at least 27 weeks in the labor force such as working or looking for work) but their incomes still fell below the official poverty level. Looking at the demographic characteristics of this population, the number of women classified as working poor is about 5.5 million compared to men which is 4.9 million. African American and Hispanics generally were more likely than White and Asians to be included among the working poor. In 2011, Blacks represent a total of $13.3 \%$ and $12.9 \%$ of Hispanics were considered to be working poor in 2011 compared to only $6.1 \%$ of Whites and $5.4 \%$ of Asians (BLS, 2013a.)

Education attainment definitely is a key factor towards reducing poverty. More advanced education is positively correlated with higher wages. Of all the people in the labor force for 27 weeks or more reported in 2011 by BLS (2013a), only those with less than a high school diploma had a higher working-poor rate of $20.1 \%$ compared to $9.2 \%$ of those with high school graduates with no college degree. Those with associate's degree are around $4.6 \%$ compared with only $2.4 \%$ of those with bachelor's degree or higher. (See Table 2.)

It is evident that high earnings in some occupations required higher education; and higher educated workers with full time jobs are less likely to live in poverty. However, low earnings, periods of unemployment and involuntary part-time employment are related to major labor market problems that impede a worker's ability to earn an income above the poverty level. For example, $84 \%$ of the working poor who usually worked full time experienced at least one of the major labor market problems 
in 2011 , and $66 \%$ are subject to low earnings which is due to one or more of the described labor market problems. Another 39\% experienced unemployment separately or in conjunction with other problems while $6 \%$ of the working poor experienced all three major problems of low earnings, unemployment, and involuntary part-time employment (BLS, 2013b).

Table 2: Poverty status of persons and primary families in the labor force for 27 or more weeks between $2007-2011$

(Numbers in thousands)

\begin{tabular}{|l|l|l|l|l|l|}
\hline Characteristic & $\mathbf{2 0 0 7}$ & $\mathbf{2 0 0 8}$ & $\mathbf{2 0 0 9}$ & $\mathbf{2 0 1 0}$ & $\mathbf{2 0 1 1}$ \\
\hline $\begin{array}{l}\text { (1)Total per- } \\
\text { sons }\end{array}$ & 146567 & 147838 & 147902 & 146859 & 147475 \\
\hline In poverty & 7521 & 8883 & 10391 & 10512 & 10382 \\
\hline $\begin{array}{l}\text { Working poor } \\
\text { rate }\end{array}$ & 5.1 & 6.0 & 7.0 & 7.2 & 7.0 \\
\hline $\begin{array}{l}\text { Unrelated in- } \\
\text { dividuals }\end{array}$ & 33226 & 32785 & 33798 & 34099 & 33731 \\
\hline In poverty & 2558 & 3275 & 3947 & 3947 & 3621 \\
\hline $\begin{array}{l}\text { Working poor } \\
\text { rate }\end{array}$ & 7.7 & 10.0 & 11.7 & 11.6 & 10.7 \\
\hline $\begin{array}{l}\text { (2)Primary } \\
\text { families }\end{array}$ & 65158 & 65907 & 65467 & 64931 & 66225 \\
\hline In poverty & 4169 & 4538 & 5193 & 5269 & 5469 \\
\hline $\begin{array}{l}\text { Working poor } \\
\text { rate }\end{array}$ & 6.4 & 6.9 & 7.9 & 8.1 & 8.3 \\
\hline
\end{tabular}

Note: (1) Includes persons in families, not shown separately. (2) Primary families with at least one member in the labor force for more than half the year

Source: U.S Bureau of Labor Statistics, Current Population Survey (CPS), Annual Social and Economic Supplements (ASEC) (BLS, 2013a).

According to the BLS July release (2012a) the average person born in the latter years of the baby boom (1957-1964) held 11.3 jobs from age 18 to age 46. Nearly half of these jobs were held from ages 18 to 24. These findings are from the National Longitudinal Survey of Youth in 1979; a survey of 9,964 men and women who were ages 14 to 22 when first interviewed in 1979 and ages 45 to 53 when interviewed most recently in 2010-11. The survey spans more than three decades and provides information on work and non-work experiences, education, training, income and assets, health, and other characteristics.

This release of the latest data from the longitudinal survey focuses on the number of jobs held, job duration, labor force participation, and earnings growth. Highlights from the survey are below:

- Individuals born from 1957 to 1964 held an average of 11.3 jobs from ages 18 to 46 . These baby boomers held an average of 5.5 jobs while ages 18 to 24 . The average fell to 3 jobs from ages 25 to 29 , to 2.4 jobs from ages 30 to 34 , and to 2.1 jobs from ages 35 to 39 and also from ages 40 to 46 . Jobs that span more than one age group were counted once in each age group, so the overall average number of jobs held from age 18 to age 46 is less than the sum of the number of jobs across the individual age groups.

- Although job duration tends to be longer the older a worker is when starting the job, these baby boomers continued to have large numbers of short-duration jobs even at middle age. 
Among jobs started by 40 to 46 year olds, 33 percent ended in less than a year, and 69 percent ended in less than 5 years.

- The average person was employed during 78 percent of the weeks from age 18 to age 46. Generally, men spent a larger percent of weeks employed than did women (84 versus 71 percent). Women spent much more time out of the labor force (25\% of weeks) than did men $(10 \%$ of weeks).

- The average annual percent growth in inflation-adjusted hourly earnings was fastest when workers were in their late teens and early twenties. Growth rates in earnings generally were higher for college graduates than for workers with less education. (BLS, 2012a).

The commitment and investment in education that Americans have made to achieve higher levels of educational attainment reflect their realization of the present and future benefits of education for labor market success through more opportunity and higher wage earning potential. The 101.1 million Americans ages 25 and older who had completed some postsecondary education in 2005 constituted a valuable national asset of knowledge, skill, and experience. Of these, 18.4 million were advance degree holders, 34.5 million had a bachelor's degree, 16.5 million had completed 2-year associate or vocational degree programs, and 31.8 million had some college education but no degree. The $21^{\text {st }}$ century labor market seeks and rewards workers who can offer the educational foundation, technical skills, and creative flexibility that employers need to compete and to adapt to changing needs successfully. Higher educational attainment contributes to a worker's ability to absorb efficiently new knowledge and to learn new skills. Workers who can quickly move up the learning curve of a new job have a competitive advantage for economic success (U.S. Department of Labor, 2006).

The Perkins Act of 2016 has provided federal resources to augment technical education and worker training across secondary and post-secondary educational settings. Since one of the purposes of the Perkins Act of 2006 is to develop more fully the academic and career and technical skills of secondary and postsecondary education students who elect to enroll in career and technical education programs, it holds secondary technical programs, community colleges, and their governing agencies accountable for student outcomes. It seeks to build on the efforts of states and localities to develop challenging academic and technical standards and to assist students in meeting such standards, including preparation for high-skill, high-wage, or high-demand occupations in current or emerging professions. The full impact of this legislation has yet to be determined. However, state agencies will continue to be required to develop methods to assess performance outcomes with some flexibility in determining how these indicators are measured (Carl D. Perkins Career and Technical Education Improvement Act, 2006).

One of the challenges to capitalism is Karl Marx's philosophy, which states that education has been taken over by capitalists for the purpose of controlling the labor force and keeping it from striving beyond its designated status (D. K. Brown, 2001). Community colleges and occupational courses specifically, have provided opportunity for advancement for many who have been unable to obtain access to the higher levels of education. Given that this is a capitalistic society in which class disparity continues, community colleges provide education and training to many individuals who would be unable to achieve such advancement by other means.

\section{EDUCATION AND TRAINING}

Education and training are emphasized in business and industry as two human resource development points that are fundamental to the changing needs of employers for literate, flexible, and wellfunctioning workers. Training and education function to provide workers with different types of information related or relevant to their career opportunities and mobility (Gray \& Herr, 1998a).

According to Dewey (1916), an education that acknowledges the full intellectual and social meaning of a vocation needs to include instruction through the historic background of present conditions. 
Training, on the other hand, fosters intelligence and initiative in dealing with the varied aspects of an occupation, as well as bringing future workers a view of the current state and future potential of their employment. In the following paragraphs, education and training are examined in more detail and then compared to determine differences between training and education.

\section{EDUCATION}

Education enables both individuals and society to advance to higher levels of development. Dewey (1916) said that education,

...is neither a process of unfolding from within nor is it a training of faculties resident in mind itself. It is rather the formation of mind by setting up certain associations or connections of content by means of a subject matter presented from without. Education proceeds by instruction taken in a strictly literal sense, a building into the mind from without. Education is a reconstruction or reorganization of experience which adds to the meaning of experience, and which increases ability to direct the course of subsequent experience. (p. 69)

\section{TRAINING}

Training has been defined in different, though similar, ways. According to Lawrie (1990), training is defined as a "change in skills" (p. 44). Emphasizing this point of view, Rothwell and Sredl (1992) suggest that training's major focus is on acquisition of knowledge and skills to enable workers to understand and perform tasks. The Rothwell and Sredl view can be further extended to suggest that "training is a short-term learning intervention intended to establish —or improve-a match between present job requirements and individual knowledge, skills, and attitudes" (p. 4). Training, differing from education, provides teaching procedures for people to perform a certain task.

\section{EDUCATION VERSUS TRAINING}

Training is a change in skills while education is a change in knowledge. According Gray and Herr (1998b), there are differences between education and training. Training is a procedure that teaches people to follow assigned procedures and perform them in an adept form or manner, while education is to "create independent problem solvers who have sufficient depth of understanding to figure what to do when the procedures breakdown" (p. 159).

Finally, the goals of both education and training are consistent. Education is consistent with the constructivist view of learning, such as instruction that prepares someone for occupations such as mechanical repair, the method of which is defined as Socratic discovery -a method of "guiding students to discovery by asking open-ended questions" This discovery is a highly disciplined process that acts as the logical equivalent of the inner critical voice which the mind develops when it develops critical thinking abilities. Training is consistent with behaviorist philosophy discovery and is defined as competency-based education for occupations that follow critical procedures such as in health care. "At the heart of the issue is the practice of designing instruction to achieve behavioral/performance objectives that are predetermined by the trainer or management versus letting the learners determine their own objectives." In workforce education, trainers who design instruction that includes opportunities to trouble-shoot a mechanical or electromechanical system are providing an opportunity for discovery or constructivist teaching (Gray \& Herr, 1998b, p.158, 295). 


\section{Table 3. Comparison of Education and Training \\ Education \\ Training}

...is concerned with the development of the mind and the intellect.

...is a more personal activity in that its main purpose is the enhancement of an individual's ability to use his mind for his own personal pleasure or gain.

....is learning.

...enables students to see the forest and the trees. It encourages general approaches to problem solving and inculcates ways of thinking that are productive, effective, and rewarding. An education prepares a student to deal with and solve a broad range of problems, and to choose which problems are important and which are not.

...has a role that attempts to establish an understanding about relationships and lead to shared perspective and an ability to predict outcomes.

....is to learn, to think, to reason.

....is learning how to learn.

...is a change of knowledge

....is centered on a base of information.

...is usually in a formal classroom setting.

... acknowledges the full intellectual and social meaning of a vocation needs to include instruction through historical background of present conditions.

...creates individuals with problem-solving skills who can find solutions when there is a breakdown in normal processes or procedures.

...is a reconstruction or reorganization of experience that adds to the meaning of experience, which increases the ability to direct the course of subsequent experience. ...prescribes to the constructivist view of learning - learning and preparation for occupations. ...deals with learning specific skills.

... develops skills that will be used more for social and economic reasons than for the self.

...is doing.

...is a narrowly focused program that leads to high proficiency in a specific skill. It prepares a student for one particular job or activity but provides neither broad perspective nor flexibility of approach.

...has a role of overcoming an operational limitation.

...is the acquisition of skills.

.... is how to perform a job.

....is a change of skills.

....is client-centered.

...may be on the job or in a school laboratory/classroom setting.

...fosters intelligence and initiative in dealing with the varied aspects of an occupation, as well as bringing future workers a view of the current state and future potential of their employment.

...teaches people to follow assigned procedures and perform them to the best of their abilities.

... is thought to be a short-term learning intervention to improve or develop skills in specific areas.

...prescribes to the behaviorist view of learning competency-based education that requires following critical procedures to perform a task. 


\section{JoB Training AND ECONOMIC GROWTH}

The United States needs economic growth for occupational opportunities and to be competitive globally, and economic growth can be driven by leading-edge technologies. The country needs suppliers of risk capital who understand the various industries in which these developments are taking place, knowledgeable people who are in a position to make educated investment decisions, specialized suppliers who can deliver high quality on time, and a strong supply of well-educated and highly trained people capable of doing the work at every level from technicians to engineers. An ecological balance is needed in all industries (not just those at the leading edge) that would likely produce the best economic results for shareholders, workers, and communities. Adult education and public job training cannot be isolated from economic development and growth in the community.

Agencies responsible for adult education and public job training often have very little geographical reach. These agencies have rarely been in a position to contribute effectively to that growth and have not been seen as useful contributors. This results in underinvestment in a large number of people who could be making a much stronger contribution not only to their own economic well-being, but also to the entire community. Therefore, it is significant to change adult education and public job training functions to align better with the forces and institutions of economic development. We must give workers and students access to the resources they need to adapt to the changing economy to allow them to succeed in a highly competitive, knowledge-based, technology-driven global economy (National Center on Education and the Economy [NCEE], 2013).

\section{MOVING FORWARD}

The pace of change is accelerating in the American workplace because of rapid technological changes and the globalization of world markets. According to the U.S. Department of Labor, Bureau of Labor Statistics (2002), these forces are reshaping the American workplace in terms of the nature and types of jobs, the composition of America's workforce, and workers' education, skills, and experiences. Manufacturing employment as a share of the total workforce is projected to decline in the $21^{\text {st }}$ century, while the service industry is projected to increase. Community colleges will also be able to claim relevancy if their efforts to make their curriculum relevant to industry include participation in contributions to the local business community.

Institutions must clarify their mission in order to gain stability and define clearly what they are trying to accomplish in order to make changes effective. There are some organizations that refuse to do feasibility studies. For institutions, it is important to identify and address the difficulties and human obstacles that people go through during change. Change is not the same as transition. According to Bridges (2003), transition is the psychological process people go through to come to terms with a new situation. Change is external, transition is internal. It is important that the change agent communicate both the reasons for change and the probable consequences that people will experience during the time of this change, which is transition - a change people go through when they become unemployed or face a major employment obstacle in their lives.

If institutions understood those difficulties, those who suffer through job loss could be enlightened and offered constructive alternatives to get their lives back on track. This awareness would give room for individual creativity. For those individuals who resist change, because resistance is a normal part of the change process, institutions could provide short-term intervention strategies to neutralize change resistance (Beckhard \& Harris, 1987).

Through the employer, small task forces and pilot groups could be formed to conduct regular meetings with employees to pinpoint factors that need to be addressed concerning change in the workplace. Employees who attend this meeting would increase their level of commitment, and credibility with the employer could be established or enhanced. For those who feel most threatened by the change, this open, honest communication would make it less stressful for them to accept the change emotionally (Kirkpatrick \& Kirkpatrick, 2006). 
Additionally, the business and community colleges could act in tandem to help reduce the negativity and stress related to change and potential job loss. To link the business community with community colleges a new global training center collaborative could provide solid technical skills for occupational advancement. This partnership between the college and the business community could provide international business training for area businesses, and its location would provide local companies more immediate access to international business resources.

\section{INSTRUCTIONAL TECHNOLOGY AND THE WORKFORCE}

The term instructional technology (IT) presents refinements not found in educational technology. Instructional technologists are team members who are specialists in the learning process. Their job is to help faculty members define the objectives of courses of instruction, to plot the learning strategies to be employed, and to evaluate results all using technological approaches to teaching and learning. Instructional technology must make education more productive, more individual, more powerful, more immediate, and more equitable. According to Gray and Herr (1998a), "when instruction is guided by a well prepared curriculum, the curriculum guide will provide alternative instructional approaches from which the professional can choose, based on the learning environment and the learner. In a practical sense the selection of instructional modalities often begins with a consideration of what is available to instructors or trainer" (p. 162). Technical education instructors should serve as coach or facilitator of learning allowing the students to think independently out of the box and develop problem-solving skills. Both teachers and students should develop communication skills and advanced which are crucial in the workplace.

\section{SUMMARY AND CONCLUSION}

In a competitive global economy, strong skills and lifelong learning should be economically rewarded, and the nature and impact of student experiences in career and technical education could have important implications for the nation's workforce and America's place in the global economy. The federal government should continue to ensure efforts to improve the quality and availability of articulated vocational programs such as $2+2+2$ (two years of high school, 2 years of community college, and 2 years of university) and the Carl D. Perkins Vocational and Technical Education Act (Perkins III). These programs reflect both continuity with previous vocational legislation and some substantive departures, specifically in funding and accountability. Given the labor market value of college credentials, lifelong learning, and flexibility in skills, the role of career and technical education is increasingly important, especially in partnership with community colleges and 4-year institutions. An emphasis on degree completion might be at odds with the shorter-term training emphasized by the Workforce Investment Act but nevertheless, higher education credentials are strongly advisable to individuals planning and pursuing a career.

Many students attending community college are considered to be in postsecondary technical education programs. These students vary in ages, income, work experience, and previous college activity and often have different goals. Some (perhaps younger students) intend to earn an associate's degree or certificate and then transferring to 4-year institutions to pursue a bachelor's degree. Others desire to enhance their job skills or to engage in personal enrichment activities; while older students may be more interested in obtaining job skills (O'Lawrence, 2005). The comparable completion rate for students entering 4-year postsecondary programs and seeking bachelor's degrees is $61.9 \%$. Almost two thirds of students who enter these longer degree programs earn a credential of some kind (including less than a baccalaureate degree), compared with about half of students who enter shorter-term vocational associate degree programs (Silverberg et al., 2004).

The Perkins III legislation suggests that effective technical skills rest on a strong foundation of academic proficiency. For the nation to be competitive in a global economy, institutions of higher learning must continue to be responsive to the needs and demands of our changing society. An excellent and relevant education will be required in the future because a complex society such as ours with an 
influx of immigrants would not exist without workforce education and development. If we do not properly and thoroughly educate our citizens, it will be difficult to be productive, competitive, humane, and peaceful. New knowledge, skills, attitudes toward cultural awareness, training, social responsibility, and total commitment to social values are what the nation needs to remain a super power (O’Lawrence, 2007).

To remain an advanced economic power, our nation needs high levels of technical knowledge to keep the economy running effectively and to maximize opportunities for economic expansion. Globalization and technology change are transforming national economies, and the skills needed in the workforce and the ability to maintain a dominant position depend on prepared workers who can learn and adapt to the continually changing demand of the world economy. Individuals must have access to the necessary information, training, and resources needed to help them acquire the skills that will allow them to capitalize on employment opportunities in our nation's $21^{\text {st }}$ century economy.

Several factors are driving the demand for educated workers and perhaps the most recognized in the $21^{\text {st }}$ century is technology. Technology has been significant catalyst in increasing the demand for a more highly educated workforce. Many technological innovations require more educated workers to install, operate, and maintain equipment. This is particularly true for information and communications technology, both of which have led to a dramatic rise in productivity throughout the past 20 years. Technological change has introduced new occupations that require new skills and education in new subjects, and it has changed the educational requirements and skill content of many traditional occupations. The most important qualitative consideration is that telecommunications, financial, and information services, while inherent parts of the rapid growth in trade and services constitute key components of the infrastructure for the overall globalization process (Preeg, 2000).

Another factor contributing to the growing need for educational attainment is the pace of change in both technology and in the competitive conditions of global markets. The faster pace of change in the modern economy means that both employers and employees must adapt to new conditions more often than in the past. This adaptation often means greater advanced technology skills and higher education credentials. To remain competitive, employers introduce new products and utilize new and more efficient processes to produce goods or services. Employees need vital new knowledge and skills to maintain current jobs or to find new ones. An investment in the nation's future means a solid commitment to career and technical education to achieve higher levels of educational attainment and high tech workforce proficiency. This represents a firm realization of the present and future benefits of education for labor-market success. The 101.1 million Americans ages 25 and older who had completed some postsecondary education in 2005 constituted a valuable national asset of knowledge, skill, and experience. Of these, 18.4 million were advanced degree holders, 34.5 million had a bachelor's degree, 16.5 million had completed 2-year associate or vocational degree programs, and 31.8 million had some college education but no degree (U.S. Department of Labor, 2006). The $21^{\text {st }}$ century labor market seeks and rewards workers who can offer the educational foundation, technical skills, and creative flexibility that employers need to compete and adapt to changing needs successfully. Higher educational attainment contributes to a worker's ability to absorb efficiently new knowledge and to learn new skills. Workers who can quickly move up the learning curve of a new job have a competitive advantage for economic success. This results in a more dynamic economy and more knowledgeable employees who are prepared for the technological challenges of the $21^{\text {st }}$ century workplace. 


\section{REFERENCES}

Allen, H. L. (2002, Fall). The best of times, the worst of times: American higher education in the $21^{\text {st }}$ century. The NEA Higher Education Journal, 91-102.

Barrow, C. W. (2000, Fall). The new economy and restructuring higher education. The NEA Higher Education Journal, 65-81.

Beckhard, R., \& Harris, R.T. (1987). Organizational transitions: Managing complex change (Addison-Wesley series on organization development). Addison-Wesley Press

Bridges, W. (2003). Managing transitions: Making the most of change (3rd ed.). Da Capo Lifelong Books.

Brown, D. K. (2001). The social sources of educational credentialism: Status cultures, labor markets, and organizations. Sociology of Education, 74, 19-34.

Brown, S. P. \& Siegel, L. B. (2005, August). Mass layoff data indicate outsourcing and offshoring work. Monthly labor review. Retrieved from http://www.bls.gov/opub/mlr/2005/08/art1full.pdf

Bureau of Labor Statistics. (2012a, July 25). Economic news release: Number of jobs beld, labor market activity, and earnings growth among the youngest baby boomers: Results from a Longitudinal Survey Summary. Retrieved from: http://www.bls.gov

Bureau of Labor Statistics. (2012b, August 24). Economic news release: Worker displacement: 2009-2011. Retrieved from: http://www.bls.gov/news.release/disp.nr0.htm

Bureau of Labor Statistics. (2012c, November 7). International comparisons of GDP per capita and per hour, 19602011. Division of International Labor Comparisons. Retrieved from http://www.bls.gov/ilc/intl gdp capita gdp hour.pdf

Bureau of Labor Statistics. (2013a). The employment situation-August 2013. Retrieved from http://www.bls.gov/news.release/pdf/empsit.pdf

Bureau of Labor Statistics. (2013b, December). Labor force projections to 2022: The labor force participation rate continues to fall. Monthly labor review. Retrieved from http://www.bls.gov/opub/mlr/2013/article/labor-forceprojections-to-2022-the-labor-force-participation-rate-continues-to-fall-1.htm

Bureau of Labor Statistics. (2014). The employment situation - July 2014. U.S. Department of Labor- USDL-141391. Retrieved from http://www.bls.gov/news.release/archives/empsit 08012014.pdf

Bureau of Labor Statistics. (2015, October). The employment situation - October 2015. U.S. Department of LaborUSDL-15-2125. Retrieved from http://www.bls.gov/ces/

Carl D. Perkins Career and Technical Education Improvement Act of 2006. (2006). S.B. 250, 109 ${ }^{\text {th }}$ Congress.

Cao, B., Xies, Y., \& Rodrigues, J. (2013, October 10). World Bank to sell record \$1 billion offshore rupee bonds. Bloomberg News. Retrieved from http://www.businessweek.com/news/2013-10-09/world-bank-to-offer-1billion-rupee-bonds-to-fund-investments

Chao, E. L. (2006). Secretary's message. In America's dynamic workforce. U.S. Department of Labor, August, 2006. Retrieved July 2, 2008, from http://www.bls.gov/ces/

Dewey, J. (1916). Democracy and education: An introduction to the philosophy of education. New York, NY: The Free Press.

Doar, R. (2014, October 14). Where's the outrage? Recent income and poverty numbers show little improvement. American Enterprise Institute. Retrieved from: http://www.aei.org/article/society-and-culture/poverty/wheres-theoutrage/?utm source $=\mathrm{t}$

Farmer, E. I., \& O'Lawrence, H. (2002). Differences in characteristics of postsecondary technical students in Pennsylvania community colleges and two-year proprietary institutions. Journal of Career and Technical Education, 18(2), 47-65.

Friedman, T. L. (2007). The world is flat: A brief history of the twenty-first century. New York: Picador. 
Gordon, H. R. D. (2008). The history and growth of career and technical education in America (3rd ed.). Long Grove, IL: Waveland Press.

Gray, K. C., \& Herr, E. L. (1998a). The mission: Developing the nation's workforce. In V. Lanigan \& K. Lamarre (Eds.), Workforce education (pp. 91-214). Needham Heights, MA: Viacom.

Gray, K. C., \& Herr, E. L. (1998b). Workforce education: The basics. Needham Heights, MA: Allyn \& Bacon.

Kirkpatrick, D. L., \& Kirkpatrick, J. D. (2006). Evaluating training programs: The four levels (3rd ed.). BerrettKoehler.

Lawrie, J. (1990). Differentiate between training, education, and development. Personal Journal, 69(10), 44.

National Center on Education and the Economy (NCEE) report. (2013). In Wikipedia. Retrieved from http://en.wikipedia.org/wiki/NCEE

O'Lawrence, H. (2005). Vocational education teachers' preparation in California: A case study assessing students' perceptions and learning outcomes of distance education. Workforce Education Forum, 32(2), 58-71.

O'Lawrence, H. (2007). A case study report of a comprehensive benchmarking review of the status of vocational education students in California: Building a new relationship between community colleges and California State University System. Journal of Career and Technical Education, 23(1), 85-96.

O'Lawrence, H. (2008a). Workforce competencies: A comparison of U.S. and Jamaican experiences. In V. C. X. Wang \& K. P. King, Innovations in career and technical education: Strategic approaches towards workforce competencies around the globe (pp.193-217).

O'Lawrence, H. (2008b). Comparative new trends in career and technical education around the globe. International Journal of Vocational Education and Training, 16(1), 95-118.

O'Lawrence, H. (2013). The historical critique of career \& technical education in California from 1900-2000 and the status of California community colleges in the $21^{\text {st }}$ century. Santa Rosa, CA, USA: Informing Science Press.

O'Lawrence, H. (2016). Managing workforce development in the $21^{\text {st }}$ century: global reflections and forward thinking in the new millennium. Santa Rosa, CA, USA: Informing Science Press.

Preeg, E. H. (2000). The trade deficit, the dollar, and the U.S. national interest. Indianapolis, IN: The Hudson Institute.

Rothwell, W. J., \& Sredl, H. J. (1992). The ASTD reference guide to professional buman resource development roles and competencies (2nd ed.). Amherst, MA: HRD Press, Inc.

Silverberg, M., Warner, E., Fong, M., \& Goodwin, D. (2004). National assessment of vocational education: Final report to congress (Executive summary). Jessup, MD: U.S. Department of Education, Office of the Under Secretary, Policy and Program Studies Service.

Sommers, D., \& Franklin, J. (2012). Employment outlook: 2010-2020. Overview of projections to 2020. In January 2012 BLS Monthly Labor Review. Retrieved from: http://www.bls.gov

Thurow, L. (1992). Head to head: The coming economic battle among Japan, Europe, and America. New York: Morrow and Company.

U.S. Department of Labor, Bureau of Labor Statistics (2002). Statistical tables. Retrieved October 20, 2012, from Bureau of Labor Statistics web site, http://www.bls.gov/cps/wlf-databook.htm

U.S. Department of Labor. (2006). America's dynamic workeforce 2006. Retrieved July 16, 2008 from www.dol.gov

U.S. Department of Labor. (2008, May). The employment situation. . Bureau of Labor Statistics. Retrieved July 2 , 2008, from http://www.bls.gov/ces/

U. S. Department of Labor, Bureau of Labor Statistics. (2013). Economic news release. Retrieved from https://www.bls.gov/

Wessel, D. (November 7, 2014). Yes, the jobless rate fell. Here's why Americans are still gloomy. Brookings -Wall Street Journal. Retrieved from: http://www.brookings.edu/research/opinions/2014/11/07-jobless-rate-fellwessel?utm ca 


\section{BIOGRAPHY}

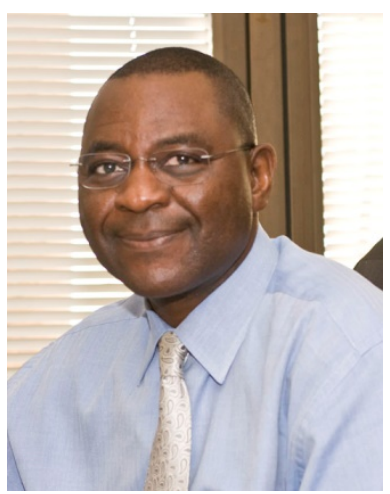

Dr. Henry O'Lawrence, a former chair of the Department of Professional Studies and full professor, is a researcher and data analyst who teaches both undergraduate and graduate courses in the Department of Health Care Administration, California State University, Long Beach. He also serves as both the thesis and project advisor for the graduate students in the department. Dr. O'Lawrence holds an associate's degree in business administration from Guilford Tech, Jamestown, North Carolina, a bachelor's degree in economics (with a minor in information systems) from Winston-Salem State University, North Carolina, a master's degree in business and marketing from the University of North Carolina, and a doctorate degree in workforce education and development from Penn State University. Dr. O'Lawrence also holds diplomas in the Leadership Management Program (MDP) from Harvard University and in Action Inquiry and Reflective Teaching from Oxford University, England; he is also a Certified Risk and Compliance Management Professional. 